\title{
Seasonal Investigation of Selected Mineral Contents in Meat, Gills, and Liver of Perch (Perca fluviatilis L.) from Western Poland
}

\author{
Magdalena Stanek ${ }^{1 *}$, Wojciech Andrzejewski ${ }^{2}$, Jan Mazurkiewicz ${ }^{2}$, \\ Bogdan Janicki ${ }^{1}$, Dorota Cygan-Szczegielniak ${ }^{1}$, Aleksandra Roślewska ${ }^{1}$, \\ Karolina Stasiak ${ }^{1}$, Iwona Waszak ${ }^{3}$ \\ ${ }^{1}$ Chair of Biochemistry and Toxicology, Faculty of Animal Breeding and Biology, \\ University of Science and Technology, Mazowiecka 28, 85-084 Bydgoszcz, Poland \\ ${ }^{2}$ Chair of Inland Fisheries and Aquaculture, Institute of Zoology, \\ Faculty of Veterinary Medicine and Animal Sciences, Poznań University of Life Sciences, \\ Wojska Polskiego 71C, 60-625 Poznań, Poland \\ ${ }^{3}$ Laboratory of Faculty, University of Science and Technology, \\ Mazowiecka 28, 85-084 Bydgoszcz, Poland
}

Received: 11 February 2015

Accepted: 15 September 2015

\begin{abstract}
The aim of our work was to compare the concentrations of zinc $(\mathrm{Zn})$, iron $(\mathrm{Fe})$, and copper $(\mathrm{Cu})$ in the meat, gills, and liver of perch (Perca fluviatilis L.) caught from lakes Góreckie, Strzeszyńskie, and Wędromierz in western Poland. The study involved 30 individual fish caught in spring, summer, and autumn. The muscle samples for analyses were taken from the large side muscle of the fish body above the lateral line. Metals concentrations were determined by atomic a Solar 969 absorption spectrophotometer (Unicam). As analysis shows, concentrations of $\mathrm{Cu}, \mathrm{Zn}$, and $\mathrm{Fe}$ detected in perch decreased in the following order: liver $>$ gills $>$ meat. The accumulation of metals decreased in the following order: $\mathrm{Fe}>\mathrm{Zn}>\mathrm{Cu}$ (in all tissues), and we observed statistically significant differences in $\mathrm{Zn}, \mathrm{Fe}$, and $\mathrm{Cu}$ concentrations in the same tissue collected from different reservoirs and during different seasons. Considering the analyses in terms of season, the average $\mathrm{Cu}$ and $\mathrm{Zn}$ contents were highest in the tissues taken in the spring. The highest concentrations of Fe were determined in samples collected during summer. The analyses indicated that concentrations of metals in tissues of fish caught from different reservoirs also showed great variation. Analysis of PCA allowed for a very good separation of the three reservoirs and three tissues investigated.
\end{abstract}

Keywords: minerals, meat, liver, gills, perch

\section{Introduction}

$\mathrm{Cu}, \mathrm{Zn}$, and $\mathrm{Fe}$ are essential elements and are carefully regulated by physiological mechanisms in most organisms.
The main roles of these elements can be described as functional and structural because of their important roles in the biological system [1]). These metals play a catalyzing role in the enzymatic systems by binding their ions to substrates, especially during oxidation-reduction

$\overline{\text { *e-mail: winiarska@utp.edu.pl }}$ 
reactions. Structurally, they stand out for their role as integrators of the body's organic compounds [2]. The content of these metals in fish body is important both with respect to nature management and human consumption of fish [3]. Copper is an essential part of several enzymes and is necessary for the synthesis of haemoglobine, and zinc is an essential micronutrient and a cofactor of nearly 300 enzymes [4].

Fish are commonly situated at the top of the food chain and they can accumulatea large amounts of some metals [5, 6]. The distribution of metals in fish body varies between fish species, depending on sex, age development, and other physiological factors such as salinity, $\mathrm{pH}$, hardness, and temperature [1, 2, 4, 7-11]. Concentrations of metals in fish tissues can reflect their previous exposures on to pollution. Fish can also be a reasonable indicators for public health standards, as well as indicators of animal health condition, because trace metals' accumulation in the aquatic food chain may reflect an ecological damage [12].

The aim of this work was to determine $\mathrm{Cu}, \mathrm{Zn}$, and $\mathrm{Fe}$ in the meat, gills, and liver tissues of perch caught from lakes Góreckie, Strzeszyńskie, and Wędromierz (Fig. 1) in western Poland during spring, summer, and autumn. Differences in the metal content in various tissues may result from their different capabilities to induce metalbinding proteins such as metallothioneins, which are low molecular weight proteins with high cysteine content [3, $11,13]$. Muscles are not always a good indicator of overall fish metal contamination, and therefore it is important to analyze other tissues, such as the liver and gills [5]. Although the muscle is not an active tissue in accumulating metals, it is commonly analyzed in literature because it is the main fish part consumed by humans [12, 14]. Gills and liver are chosen as target organs for assessing metal accumulation. The concentration of metals in the gills reflects the content of metals in waters, and the concentration in liver represents storage of metals [15]. The use of multivariate methods (HCA and PCA) may afford a better understanding of the composition of meat according to the fish origin. PCA analysis provides information on the most meaningful parameters that describe the whole data interpretation and summarize the statistical correlation among metals [16].

\section{Material and Methods}

\section{Study Area}

Lake Góreckie is a dimictic lake in Wielkopolska National Park, with a surface area of ca. 104 ha, maximum and mean depths of $17.25 \mathrm{~m}$ and $8.97 \mathrm{~m}$, respectively, and a shoreline of $8,300 \mathrm{~m}$. The degree of antropopressure from annual nitrogen and phosphorus amounts for the eutrophic lake is estimated at $9.5 \mathrm{~g} \cdot \mathrm{m}^{-2} \cdot$ year $^{-1}$ for total nitrogen and 0.36 for total phosphorus $\mathrm{g} \cdot \mathrm{m}^{-2} \cdot \mathrm{year}^{-1}$ [17]. Lake

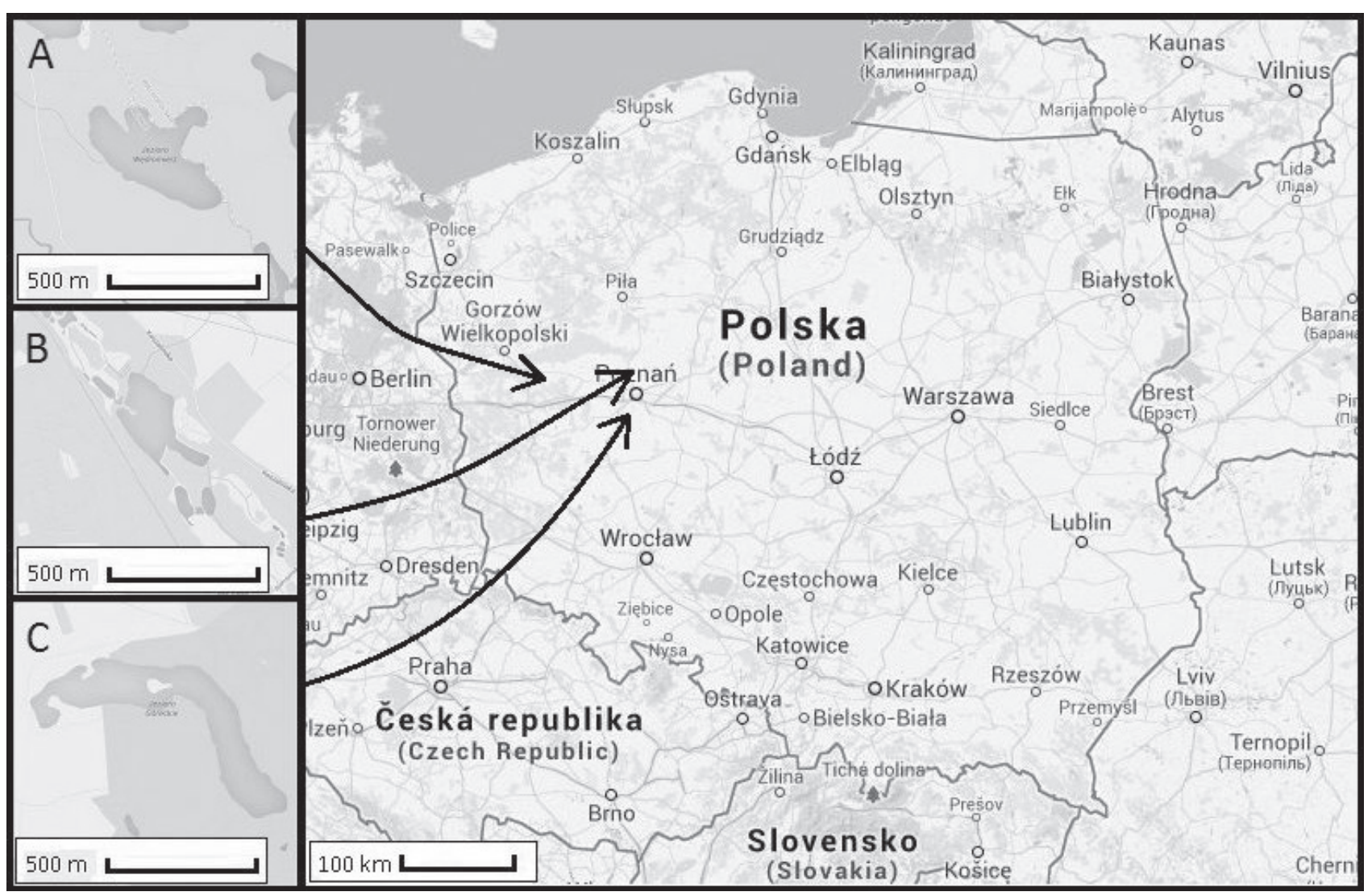

Fig. 1. Map of Poland and locations of analyzed lakes (A)Wędromierz, (B)Strzeszyńskie, (C) Góreckie. 
Strzeszyńskie has a surface area of 34.9 ha and is located within the administrative boundaries of the city of Poznan. Maximum depth is $18.8 \mathrm{~m}$ and mean depth is $8.2 \mathrm{~m}$. A shoreline of $4,500 \mathrm{~m}$ is mostly covered with deciduous and pine forests used mainly for recreational destination. The lake is used by the Polish Fishing Association. Lake Wędromierz is a flow reservoir in Pszczewski Landscape Park. It has a surface area of 73.8 ha, maximum and mean depths of $11.8 \mathrm{~m}$ and $4.9 \mathrm{~m}$, respectively, and a shoreline covered with mixed forests (Fig. 1).

Trophic levels of the lakes are based on Carlson's index [18] and calculated as an average for three seasons (spring, summer, and autumn). The basis for the calculations were the results of analyzing Secchi disk visibility, chlorophyll concentrations, and the concentrations of total phosphorus in the surface layer (2012). The obtained values of Carlson index were: Góreckie 71, Strzeszyńskie 63, and Wędromierz 83. On this basis, all the lakes were classified as eutrophic. The conditions of the Wędromierz catchment causes unfavorable changes, i.e., class III susceptibility to degradation of the water body, which has an adverse effect on the quality of water [19]. Ecological status of this reservoir is classified as moderate [20]. Water of Strzeszyńskie was estimated to be in second purity class $[21,22]$. Strzeszyńskie can be classified as relatively highly resistant to human impact, and the general vulnerability of this reservoir was designated as category $2[23,24]$. The trophic state of Góreckie was determined as hypertrophic [25]. For more than 20 years this lake had been polluted with raw waste from the nearby sanatorium in Jeziory [26].

\section{Fish Samples}

The study involved 90 individual perch (Percafluviatilis L.) caught in spring (April 13-25), summer (July 9-25), and autumn (October 9-November 6). The experimental fish were obtained from their natural environment from the Wielkopolska Lake District. Measurements of the mass of the fish body (BW) $( \pm 0.01 \mathrm{~g})$, body length (Lc) $( \pm 0.1 \mathrm{~cm})$, and total length $(\mathrm{Lt})( \pm 0.1 \mathrm{~cm})$ were taken for each individual. The meat samples for analyses were taken from the large side muscle of fish body above the lateral line. Due to the relatively low amounts of liver and gills obtained from single individuals, the material was combined (about two pieces of each). We chose for analyses individuals with similar biometric measurements. Body weights ranged from 165 to $295 \mathrm{~g}$, and body length and total length were from 17.0 to $23.5 \mathrm{~cm}$ and from 19.5 to 28.5 , respectively.

The samples of fish organs were immediately frozen after preparation and were kept in a deep freezer before analyses. All frozen samples were freeze dried in a freeze drier (Finn-Aqua Lyovac GT2) (parameters: temperature $-40^{\circ} \mathrm{C}$, pressure $6 \cdot 10^{-2} \mathrm{mbar}$, duration at least $48 \mathrm{~h}$ ).

The freeze dried samples were mineralized in a microwave mineralizator (Ethos Plus, Milestone). For mineralization $0.1 \mathrm{~g}$ of the tissue was weighted and then $\mathrm{HNO}_{3}$ and $\mathrm{H}_{2} \mathrm{O}_{2}$ were added at a ratio of $4: 1$. During the first 10 minutes, the temperature was increased to $190^{\circ} \mathrm{C}$. During the next seven minutes the temperature was kept at a level of $190 \pm 5^{\circ} \mathrm{C}$. The mineralized samples were carried quantitatively to the measuring flask with a capacity of $50 \mathrm{~cm}^{3}$.

Copper, zinc, and iron concentration was determined using a Solar 969 atomic absorption spectrophotometer (Unicam). Tissue concentrations of minerals have been reported as $\mathrm{mg} \cdot \mathrm{kg}^{-1}$ dry weight $\left(\mathrm{mg} \cdot \mathrm{kg}^{-1} \mathrm{~d}\right.$. w.). Certified ICP standards of Merck were used in the calibration and validation of the standard curves. The concentrations of the metals were calculated from linear calibration plots obtained by measurement of the standard solutions. All

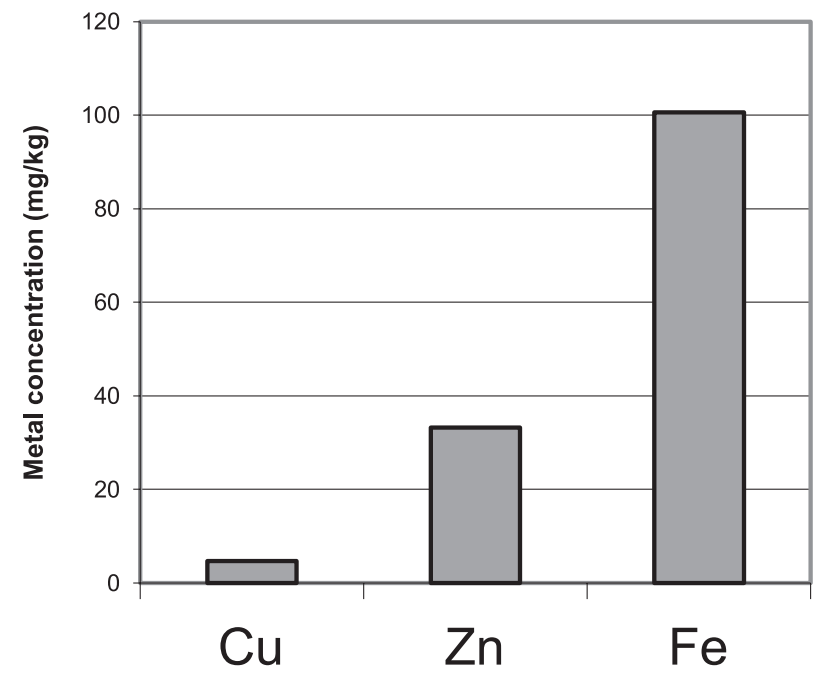

a) meat

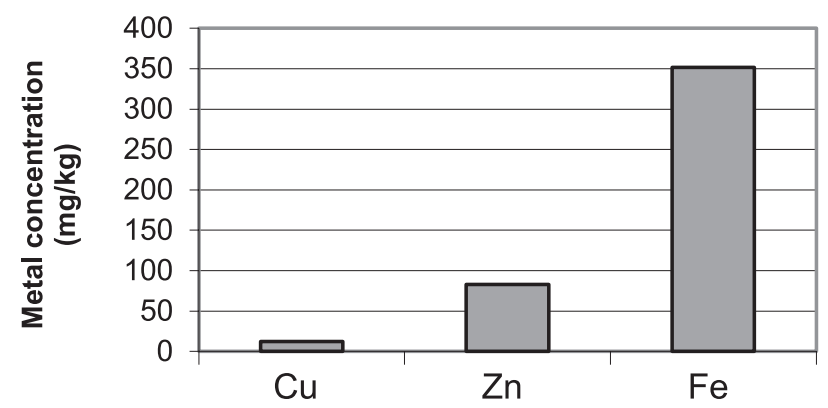

b) liver

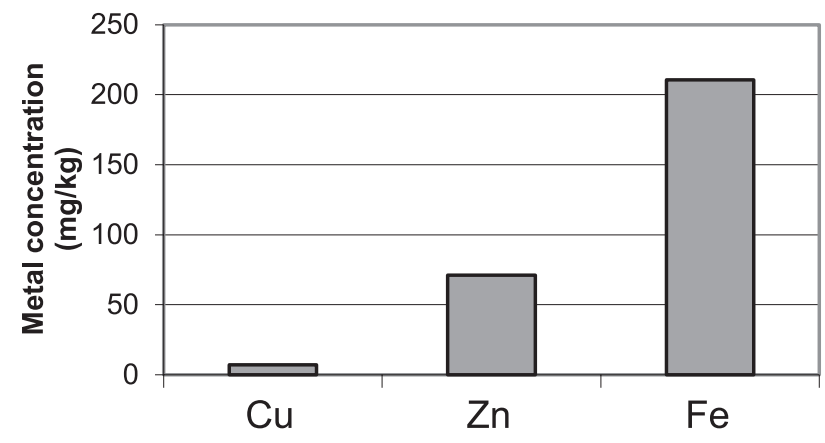

c) gills

Fig. 2. Range of the metal concentrations in different tissues of perch a) meat, b) liver, and c) gills. 
Table 1. Mean concentrations of $\mathrm{Zn}, \mathrm{Fe}$, and $\mathrm{Cu}$ in the meat of perch (Perca fluviatilis L.).

\begin{tabular}{|c|c|c|c|c|}
\hline \multirow{3}{*}{ Fishing period } & \multirow{2}{*}{ Reservoir } & \multicolumn{3}{|c|}{$\begin{array}{c}\text { Metal concentrations } \\
\left(\mathrm{mg} \cdot \mathrm{kg}^{-1} \text { dry weight }\right)\end{array}$} \\
\cline { 2 - 5 } & & $\mathrm{Zn}$ & $\mathrm{Fe}$ & $7.11 \pm 0.22^{\mathrm{a}}$ \\
\hline \multirow{3}{*}{ Spring } & Góreckie & $60.84 \pm 1.34^{\mathrm{a}}$ & $30.41 \pm 1.13^{\mathrm{a}}$ & $4.52 \pm 0.17^{\mathrm{b}}$ \\
\cline { 2 - 5 } & Strzeszyńskie & $26.99 \pm 0.36^{\mathrm{b}}$ & $23.09 \pm 1.12^{\mathrm{b}}$ & $1.98 \pm 0.23^{\mathrm{c}}$ \\
\cline { 2 - 5 } & Wędromierz & $44.18 \pm 4.57^{\mathrm{c}}$ & $17.94 \pm 0.23^{\mathrm{b}}$ & $6.09 \pm 0.22^{\mathrm{d}}$ \\
\hline \multirow{3}{*}{ Summer } & Góreckie & $16.94 \pm 0.63^{\mathrm{d}}$ & $267.93 \pm 3.35^{\mathrm{d}}$ & $5.19 \pm 0.28^{\mathrm{e}}$ \\
\cline { 2 - 5 } & Strzeszyńskie & $25.50 \pm 0.96^{\mathrm{b}}$ & $263.87 \pm 2.53^{\mathrm{d}}$ & $2.67 \pm 0.32^{\mathrm{f}}$ \\
\cline { 2 - 5 } & Wędromierz & $20.50 \pm 0.51^{\mathrm{e}}$ & $263.02 \pm 11.13^{\mathrm{d}}$ & $7.52 \pm 0.28^{\mathrm{g}}$ \\
\hline \multirow{3}{*}{ Autumn } & Góreckie & $40.50 \pm 2.03^{\mathrm{f}}$ & $17.66 \pm 0.76^{\mathrm{b}, \mathrm{c}}$ & $4.54 \pm 0.16^{\mathrm{b}}$ \\
\cline { 2 - 5 } & Strzeszyńskie & $30.72 \pm 2.02^{\mathrm{g}}$ & $9.20 \pm 0.36^{\mathrm{c}}$ & $2.68 \pm 0.28^{\mathrm{f}}$ \\
\cline { 2 - 5 } & Wędromierz & $33.06 \pm 2.09^{\mathrm{g}}$ & $12.71 \pm 0.43^{\mathrm{b}, \mathrm{c}}$ & \multicolumn{2}{|c|}{} \\
\hline
\end{tabular}

The values marked with different letters in the same column are significantly different $(p \leq 0,05$, Tukey's test).

Table 2. Mean concentrations of $\mathrm{Zn}, \mathrm{Fe}$, and $\mathrm{Cu}$ in the liver of perch (Perca fluviatilis L.).

\begin{tabular}{|c|c|c|c|c|}
\hline \multirow{3}{*}{ Fishing period } & \multirow{2}{*}{ Reservoir } & \multicolumn{3}{|c|}{$\begin{array}{c}\text { Metal concentrations } \\
\left(\mathrm{mg} \cdot \mathrm{kg}^{-1} \text { dry weight }\right)\end{array}$} \\
\cline { 2 - 5 } & & $\mathrm{Zn}$ & $\mathrm{Fe}$ & $16.35 \pm 0.20^{\mathrm{a}}$ \\
\hline \multirow{3}{*}{ Spring } & Góreckie & $93.12 \pm 2.12^{\mathrm{a}, \mathrm{b}}$ & $288.99 \pm 11.82^{\mathrm{a}}$ & $15.87 \pm 0.33^{\mathrm{a}}$ \\
\cline { 2 - 5 } & Strzeszyńskie & $96.19 \pm 3.82^{\mathrm{a}}$ & $434.53 \pm 8.41^{\mathrm{b}}$ & $18.73 \pm 0.75^{\mathrm{b}}$ \\
\cline { 2 - 5 } & Wędromierz & $91.91 \pm 1.10^{\mathrm{a}, \mathrm{b}}$ & $525.02 \pm 13.32^{\mathrm{c}}$ & $8.53 \pm 0.26^{\mathrm{c}}$ \\
\hline \multirow{3}{*}{ Summer } & Góreckie & $49.22 \pm 1.83^{\mathrm{c}}$ & $472.94 \pm 11.84^{\mathrm{d}}$ & $12.72 \pm 0.90^{\mathrm{d}}$ \\
\cline { 2 - 5 } & Strzeszyńskie & $67.31 \pm 3.19^{\mathrm{d}}$ & $373.52 \pm 28.65^{\mathrm{e}}$ & $13.13 \pm 0.27^{\mathrm{d}}$ \\
\cline { 2 - 5 } & Wędromierz & $43.91 \pm 1.23^{\mathrm{c}}$ & $446.51 \pm 11.42^{\mathrm{b}, \mathrm{d}}$ & $8.25 \pm 0.14^{\mathrm{c}}$ \\
\hline \multirow{3}{*}{ Autumn } & Góreckie & $107.39 \pm 6.24^{\mathrm{e}}$ & $269.99 \pm 20.91^{\mathrm{a}}$ & $9.67 \pm 0.78^{\mathrm{e}}$ \\
\cline { 2 - 5 } & Strzeszyńskie & $105.66 \pm 1.42^{\mathrm{e}}$ & $196.97 \pm 6.51^{\mathrm{f}}$ & $7.51 \pm 0.38^{\mathrm{c}}$ \\
\cline { 2 - 5 } & Wędromierz & $88.79 \pm 2.18^{\mathrm{b}}$ & $155.75 \pm 15.76^{\mathrm{g}}$ & 7.05 \\
\hline
\end{tabular}

The values marked with different letters in the same column are significantly different ( $p \leq 0,05$, Tukey's test).

Table 3. Mean concentrations of $\mathrm{Zn}, \mathrm{Fe}$, and $\mathrm{Cu}$ in the gills of perch (Perca fluviatilis L.).

\begin{tabular}{|c|c|c|c|c|}
\hline \multirow{2}{*}{ Fishing period } & \multirow{2}{*}{ Reservoir } & \multicolumn{3}{|c|}{$\begin{array}{c}\text { Metal concentrations } \\
\left(\mathrm{mg} \cdot \mathrm{kg}^{-1} \text { dry weight }\right)\end{array}$} \\
\cline { 2 - 5 } & & $\mathrm{Zn}$ & $\mathrm{Fe}$ & $14.80 \pm 0.09^{\mathrm{a}}$ \\
\hline Spring & Góreckie & $101.32 \pm 2.96^{\mathrm{a}}$ & $179.87 \pm 6.37^{\mathrm{a}}$ & $7.68 \pm 0.24^{\mathrm{b}}$ \\
\hline & Strzeszyńskie & $76.07 \pm 1.08^{\mathrm{b}}$ & $71.23 \pm 1.63^{\mathrm{b}}$ & $9.40 \pm 0.46^{\mathrm{c}}$ \\
\hline & Wędromierz & $94.98 \pm 1.88^{\mathrm{c}}$ & $155.64 \pm 27.49^{\mathrm{c}}$ & $4.90 \pm 0.20^{\mathrm{d}}$ \\
\hline Summer & Góreckie & $37.01 \pm 0.21^{\mathrm{d}}$ & $337.61 \pm 17.92^{\mathrm{d}}$ & $4.16 \pm 0.51^{\mathrm{e}}$ \\
\hline & Strzeszyńskie & $67.36 \pm 2.29^{\mathrm{e}}$ & $499.20 \pm 6.25^{\mathrm{e}}$ & $5.99 \pm 0.13^{\mathrm{f}}$ \\
\hline & Wędromierz & $42.86 \pm 0.41^{\mathrm{f}}$ & $298.56 \pm 6.29^{\mathrm{f}}$ & $5.00 \pm 0.28^{\mathrm{d}}$ \\
\hline & Góreckie & $79.12 \pm 3.33^{\mathrm{b}}$ & $118.64 \pm 4.36^{\mathrm{g}}$ & $6.35 \pm 0.17^{\mathrm{f}}$ \\
\hline & Strzeszyńskie & $75.69 \pm 2.19^{\mathrm{b}}$ & $107.24 \pm 5.39^{\mathrm{g}}$ & $5.93 \pm 0.33^{\mathrm{f}}$ \\
\hline
\end{tabular}

The values marked with different letters in the same column are significantly different ( $\leq \leq 0,05$, Tukey's test). 
determinations were made in triplicate and the data for samples of the meat were corrected to oven-dry $\left(105^{\circ} \mathrm{C}\right)$ moisture content.

\section{Statistical Analyses}

Data analyses were performed using Statistica 8.0 software (StatSoft, USA). Significance of differences in the average contents of zinc, copper, and iron in the meat, gills, and liver of perch were statistically analysed using Tukey's test. In this case, a significance of differences in the average content of metals (between the lakes and seasons within a single tissue) were calculated by two-way analysis of variance (ANOVA). The normality of data was tested using Shapiro-Wilk's test, and the homogeneity of variance was tested with Levene's test. The analysis of correlations between metals concentrations were done. Pearson rank correlation coefficient (r) was calculated. The classifications and discriminations of different seasons and tissues were achieved by cluster analysis (CA) and principal component analysis (PCA).

\section{Results and Discussion}

The analyses that are presented in Fig. 2 revealed the accumulation of metals in the following order: $\mathrm{Fe}>\mathrm{Zn}>$ $\mathrm{Cu}$ (in all tissues) and we observed statistically significant differences in $\mathrm{Zn}, \mathrm{Fe}$, and $\mathrm{Cu}$ concentrations in the same tissue collected from different reservoirs and during different seasons.

The same tendency was observed by Klavins et al. [27] in perch tissues collected from the lakes in Latvia, by Radwan et al. [28] in pike from Lake Piaseczno, and in tissues of fish from Iran's Anzali Wetland [29]. In fish organs collected from northwestern and northeastern Poland, metals were ordered as follows: $\mathrm{Zn}>\mathrm{Fe}>\mathrm{Mn}>$ $\mathrm{Cu}[30,31]$. As the analyses indicated, concentrations of metals were higher in the liver than in any other tissues (Fig. 3). It appears that the concentrations of all metals behave in a similar way in the examined tissues. The liver is the major organ involved in xenobiotic metabolism in fish through specific binding proteins known as metallothioneins $[3,11,13]$. It is well known that a large amount of metallothioneins occurs in the liver cells of fish because metals mainly accumulate in metabolically active tissues.

The mean values of $\mathrm{Zn}$ in the liver and gills were very similar (during spring and summer) and the concentrations of $\mathrm{Fe}$ and $\mathrm{Cu}$ were significantly higher in the liver (Tables 1-3).

The gills play active and passive roles in exchanges between the animal and its aquatic environment [32], and as Brooks and Rumsey [33] observed, the gills are the major storage sites for $\mathrm{Zn}$ in several species of fish in New Zealand. Increased levels of $\mathrm{Zn}$ in gills and liver are the consequence of increased $\mathrm{Zn}$ concentrations in plankton and sediments, which was confirmed by the analyses of Petkovsek et al. [34]. Metal absorption in fish is carried out via two uptake routes: the digestive tract and gill surface [31]. The highest concentrations of metals in the gills indicates that the element was absorbed via the respiratory tract [7]. As Fig. 3 shows, Cu, Zn, and Fe concentrations detected in perch increased in the following order: liver $>$ gills $>$ meat.

These results were in agreement with data obtained by Bochenek et al. [7], Brucka-Jastrzębska et al. [35], Canli and Atli [8], Drag-Kozak et al. [36], Dural et al. [32], Jarić et al. [5], Papagiannis et al. [3], Petkovšek et al. [34],
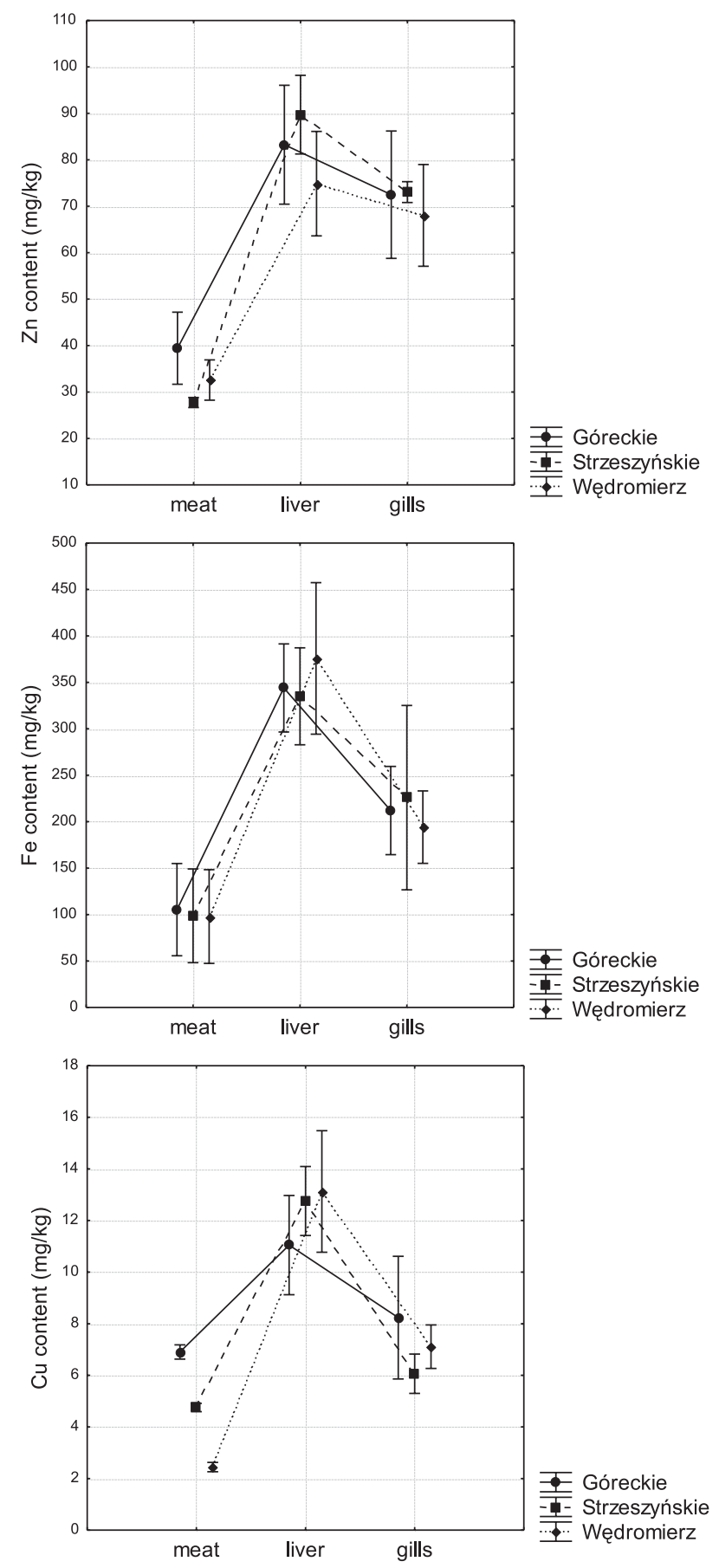

Fig. 3. The mean concentrations of $\mathrm{Zn}, \mathrm{Fe}$, and $\mathrm{Cu}(\mathrm{mg} / \mathrm{kg})$ in various tissues collected from Lakes Góreckie, Strzeszyńskie, and Wędromierz. 


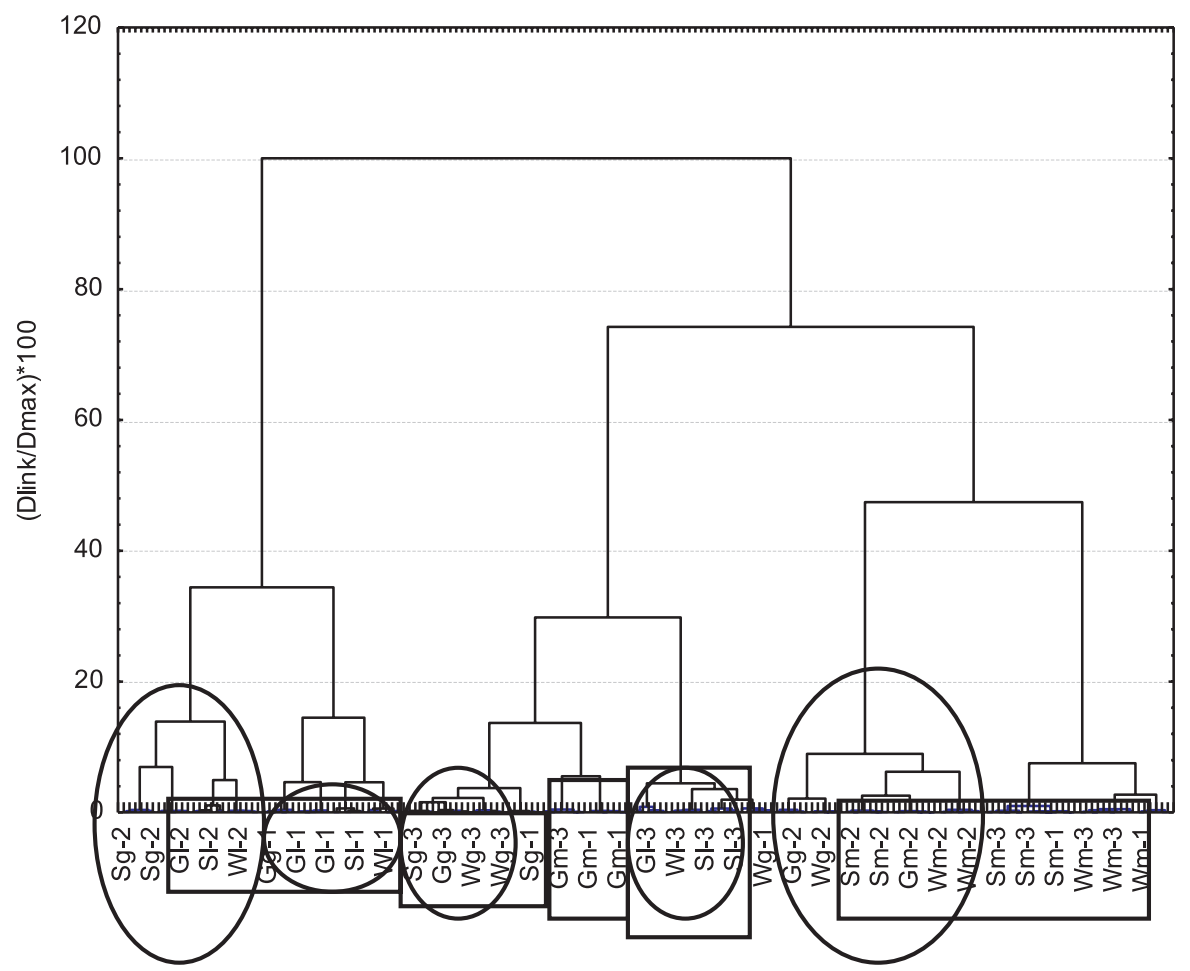

Fig. 4. The dendrogram produced by hierarchical cluster anaysis (HCA) using Ward's method and squared Euclidean distance. Abbreviations: G - Góreckie Lake, S - Strzeszyńskie Lake, W - Wędromierz Lake, g - gills, 1 - liver, m - meat, 1 - spring, 2 - summer, and 3 - autumn.

Szefer et al. [37], and Zubcov et al. [14]. The same results were observed by Yazdi et al. [29] for $\mathrm{Cu}$ determined in the tissues of Ctenopharyngo idella and Perca fluviatilis, and for $\mathrm{Zn}$ determined in the tissues of Perca fluviatilis. Muscle proved to have the lowest accumulation capacity of the investigated metals. This is important because muscle constitutes the greatest mass of the fish that is consumed. Unless fish muscle cannot be considered to be a metal-accumulating tissue, it is the ideal tissue for use in monitoring programs [27]. The recommended daily allowance of $\mathrm{Zn}$ for girls and adult women and for boys and men ranges 13-21 and $16 \mathrm{mg}$ per person, respectively. The average recommended daily allowance of $\mathrm{Fe}$ and $\mathrm{Cu}$ ranges 13-26 and 1.5-2.5, respectively [11]. Therefore, consumption of $100 \mathrm{~g}$ of an edible portion of analyzed fish would satisfy about 17.4 percent of human daily demand for $\mathrm{Zn}$, about 51.6 for $\mathrm{Fe}$, and 23.5 for $\mathrm{Cu}$.

Considering the analyses in terms of seasons, average $\mathrm{Cu}$ and $\mathrm{Zn}$ contents were the highest in the tissues taken in the spring. The highest concentration of Fe was determined in the samples collected during summer (Tables 1-3). The seasonal changes of the metal concentrations in fish may result from the intrinsic factors such as growth and reproductive cycle, and changes in water temperature [32]. The seasonal variations in the concentrations of the selected metals are probably reflected by different metal bioavailabilities, depending on the ligands present in the biotopes and the chemical speciations between the dissolved and particulate phases [37]. As Yilmaz et al. [4] reported, Fe content depends on the species, individuals, and sampling period. This suggest that the highest con- centrations of this metal could be a resultsresult of individual diet.

The observed seasonal variations in the contents of $\mathrm{Cu}$, $\mathrm{Zn}$, and $\mathrm{Fe}$ in fish body may be reflected by different metal bioavailabilities, depending on the ligands present in the biotopes [36]. As the authors have concluded, the great differences presented in Fig. 3 may be due to physiological roles of the different metals in fish metabolism. Mendil et al. [2] observed that concentrations of the most frequently

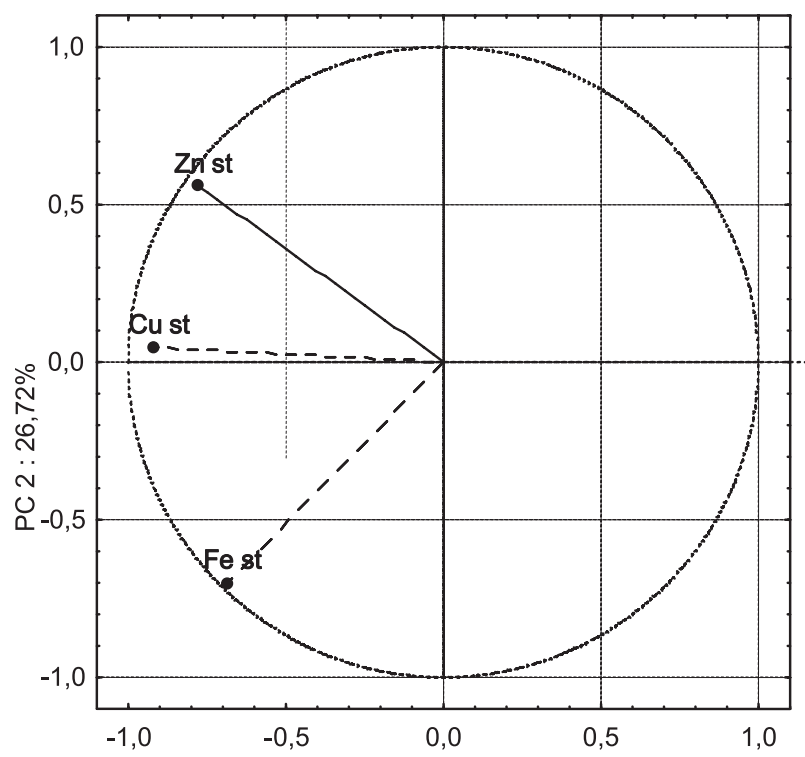

Fig. 5. Loading plot of PC1-PC2. 


\begin{tabular}{|c|c|c|}
\hline \multicolumn{3}{|l|}{ meat } \\
\hline $\mathrm{Zn}$ & -0.6489 & \\
\hline $\mathbf{C u}$ & 0.0042 & $\mathbf{0 . 2 6 7 0}$ \\
\hline & $\mathrm{Fe}$ & $\mathrm{Zn}$ \\
\hline
\end{tabular}

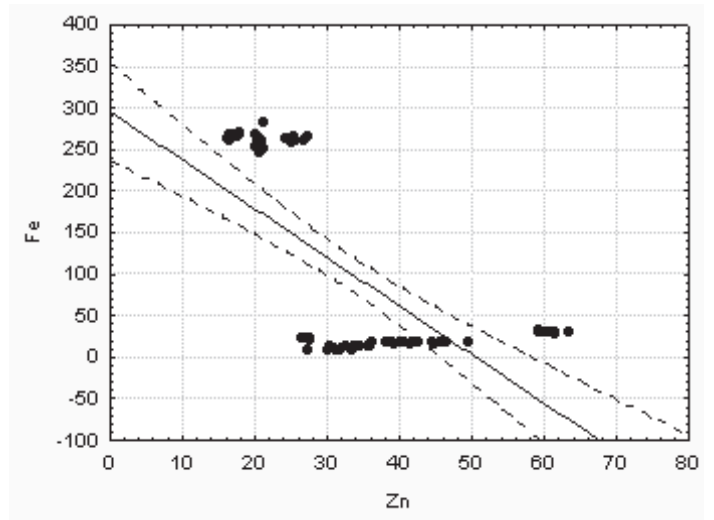

\begin{tabular}{|c|c|c|}
\hline \multicolumn{3}{|l|}{ liver } \\
\hline $\mathrm{Zn}$ & -0.5126 & \\
\hline $\mathbf{C u}$ & $\mathbf{0 . 5 8 2 4}$ & 0.0644 \\
\hline & $\mathrm{Fe}$ & $\mathrm{Zn}$ \\
\hline
\end{tabular}

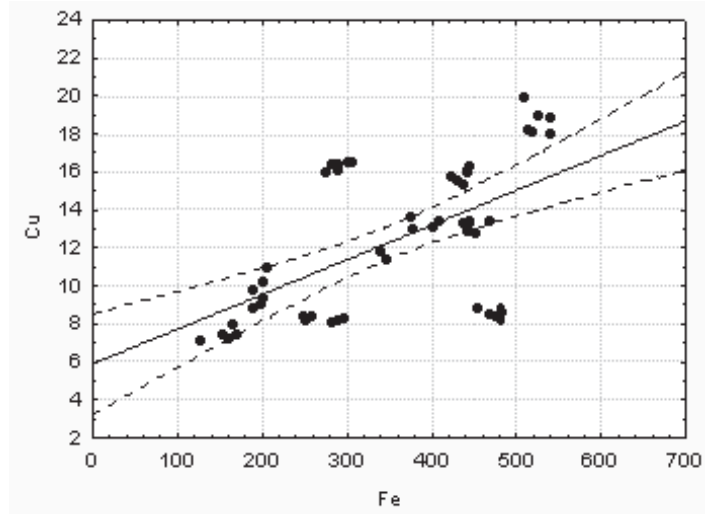

\begin{tabular}{|c|c|c|}
\hline \multicolumn{3}{|l|}{ gills } \\
\hline $\mathrm{Zn}$ & -0.4869 & \\
\hline $\mathrm{Cu}$ & -0.3543 & 0.7015 \\
\hline & $\mathrm{Fe}$ & $\mathrm{Zn}$ \\
\hline
\end{tabular}

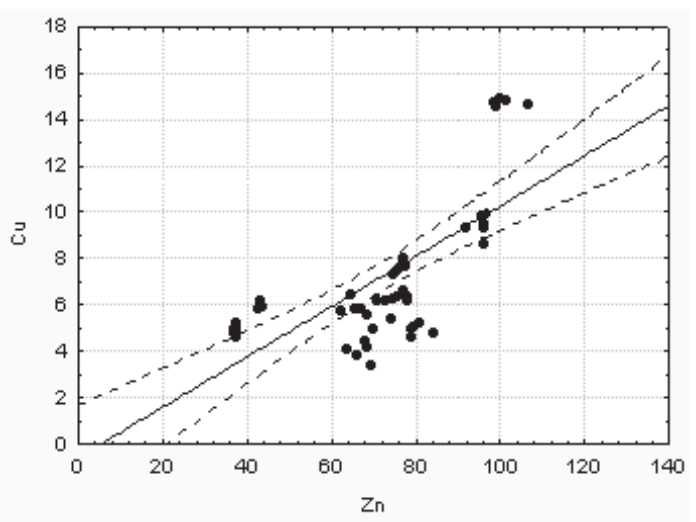

Fig. 6. Values of Pearson's rank correlations coefficient for selected metals in the meat, liver, and gills of perch (Perca fluviatilis L.) from Lakes Góreckie, Strzeszyńskie, and Wędromierz. analyzed metals (for example: $\mathrm{Fe}$ and $\mathrm{Cu}$ ) in the fish samples collected in summer, have been reported at the highest level. Most probably, the dynamics of trace element accumulation is determined by the growth rate of fish, which is the highest during summer, and by changes in the feeding rate and dynamics of lipid metabolism in the tissues [14]. Additionally, the differences noted in the metal concentrations in the different tissues between seasons could result from local pollution $[32,38]$.

The analyses indicated that the concentrations of metals in tissues of fishes collected from different reservoirs showed a great variations and statistically important differences (Tables 1-3), but similar trends in metal accumulation in various organs were observed (Fig. 3 ). These results were generally in the agreement with data published in literature. This is related to environmental conditions, changes in water temperature, and swimming activity [8]. It is a difficult to compare metal concentrations between the same tissue of two different species - or even the same species living in different reservoirs - because of different feeding habits, differences in an aquatic environmental states, growing rates of the species, types of the analyzed tissues, and other factors [4]. As BruckaJastrzębska and Protasowicki [39] indicated, levels of the bio-elements and harmful metals in the carp body depended on the culture method, water quality, and type of the feed. The rate at which metals affect the organism is related to the metal transportation function of the blood.

\section{Chemometric Analysis}

Euclidean distance was used as a similarity measurement and Ward's method as an amalgamation rule. The resulting dendrogram decsribed in Fig. 4 shows six different clusters at $\left(\mathrm{D}_{\text {link }} / \mathrm{D}_{\max }\right) \times 100$ under 20 . The clusters marked with an ellipses aggregate samples collected in the same season, and the clusters marked with a rectangle aggregate samples of the same tissue.

The data matrix of variables $(\mathrm{Cu}, \mathrm{Zn}$, and $\mathrm{Fe})$ and scores (180 fish samples) was subjected to PCA in order to decrease the number of descriptors associated with the data set. PCA is mostly used for data compression and visualization. The main goal of this method is to explain the information contained in the data by a set of the socalled principal components.

Fig. 5 illustrates the factor-loading plot for the metals. All three variables have negative loadings in $\mathrm{PC} 1$ and gathered on the left side of PC1 $\times$ PC2. PC1 showed a low negative loading from $\mathrm{Zn}, \mathrm{Fe}$ and $\mathrm{Cu}$. The highest positive loadings in $\mathrm{PC} 2$ have $\mathrm{Zn}(0.56)$.

The loadings plot can explain correlations between variables. Variables closest to each other in twodimensional space and far from the plot origin are positively correlated, and variables opposite to each other are negatively correlated. Results of the analysis of correlation are presented in Fig. 6 and show a positive - but not high - correlation between $\mathrm{Zn}$ and $\mathrm{Cu}$. Furthermore, we observed a high and statistically significant correlations between $\mathrm{Cu}$ and $\mathrm{Fe}$ in the liver. 


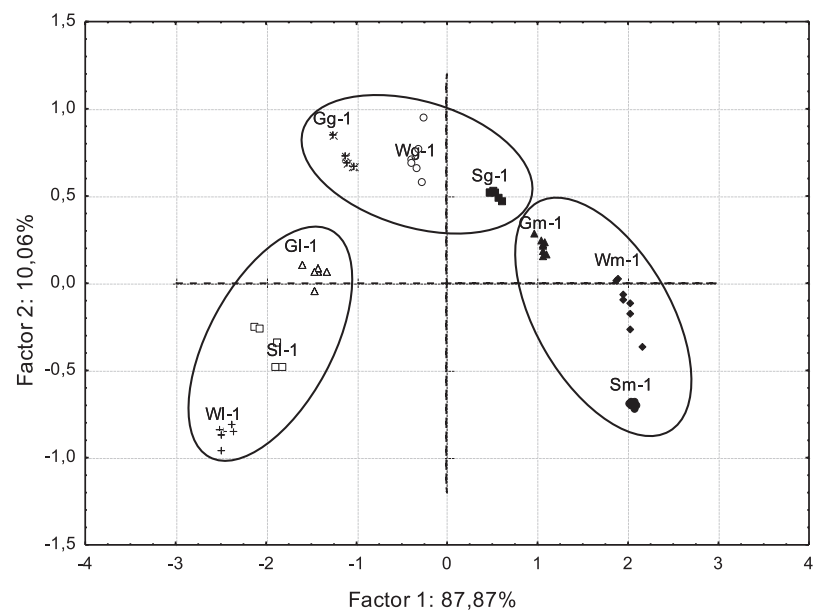

Fig. 7. Score plot for $\mathrm{PC} 1$ and $\mathrm{PC} 2$ for spring (1). Abbreviations: G - Góreckie Lake, S - Strzeszyńskie Lake, W - Wędromierz Lake, $\mathrm{g}$ - gills, 1 - liver, $\mathrm{m}$ - meat.

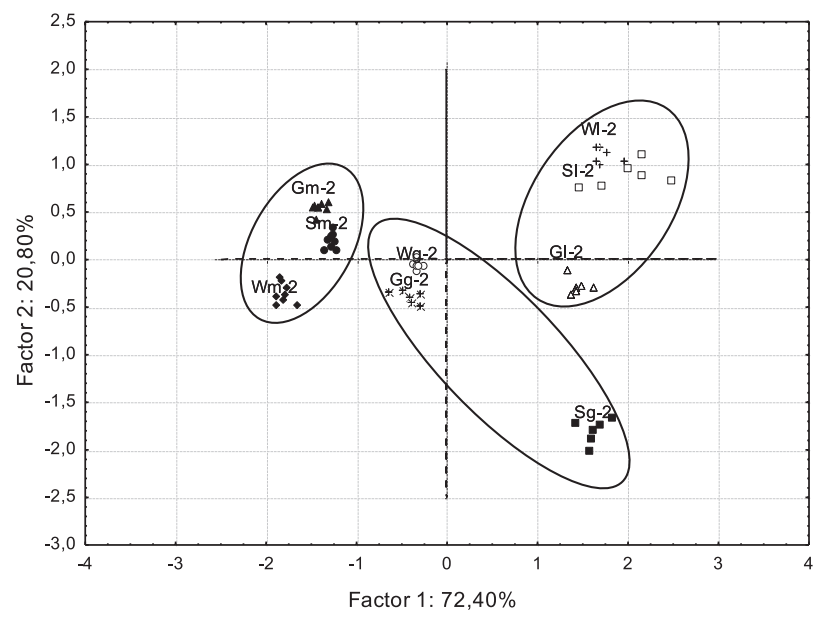

Fig. 8. Score plot for PC1 and PC2 for summer (2). Abbreviations: G - Góreckie Lake, S - Strzeszyńskie Lake, W - Wędromierz Lake, $\mathrm{g}-$ gills, 1 - liver, $\mathrm{m}-$ meat.

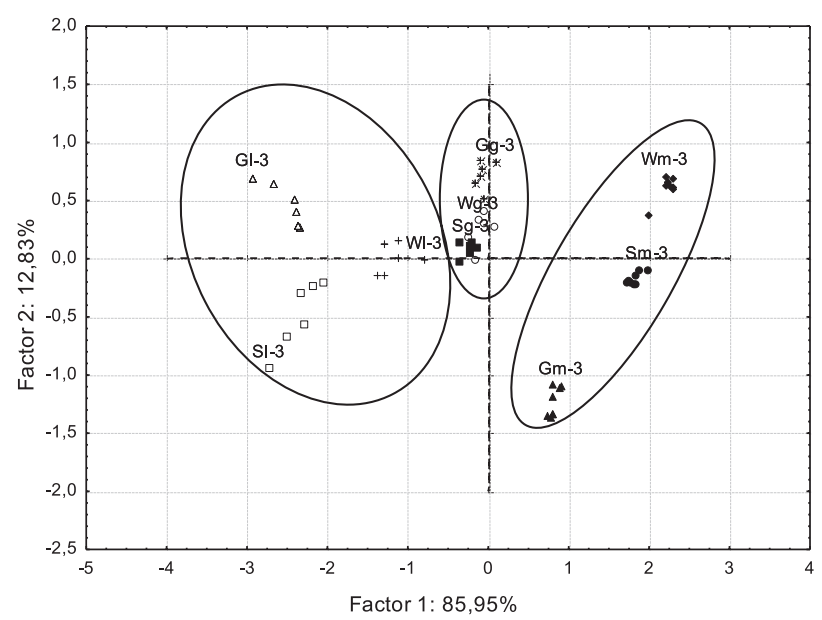

Fig. 9. Score plot for PC1 and PC2 for autumn (3). Abbreviations: G - Góreckie Lake, S - Strzeszyńskie Lake, W - Wędromierz Lake, g - gills, 1 - liver, $\mathrm{m}$ - meat.
As Brucka-Jastrzębska et al. [35] observed, absorption and metabolic function of $\mathrm{Fe}$ are dependent on influences of the other elements. For example, the relationship between $\mathrm{Fe}$ and $\mathrm{Cu}$ often has a synergetic character, because both of these metals are involved in reductionoxidation processes.

Figs 7-9 show that PC1 and PC2 scores allow for good separation of three reservoirs and three tissues investigated.

\section{Conclusions}

1. The concentrations of $\mathrm{Zn}, \mathrm{Fe}$, and $\mathrm{Cu}$ in meat were similar to the values obtained by the other authors and did not exceed the acceptable levels in food intendent for human consumption.

2. Seasonal variabilities were found in the analyzed samples, with the highest concentrations of $\mathrm{Zn}$ and $\mathrm{Cu}$ occurring in spring and $\mathrm{Fe}$ in the summer. The highest concentrations of $\mathrm{Fe}$ that were determined in samples collected during summer suggest greater elution of iron from sediments at higher temperatures.

3. There were observed differences in the content of elements depending on lake type. Analysis of PCA allowed for very good separation of the three reservoirs and three tissues investigated, because there were statistically significant differences in the accumulation of metals in the organs of fish caught from different reservoirs. But the tendency of metals accumulation in the organs increased in the following order: liver $>$ gills $>$ meat.

\section{References}

1. FALLAH A.A., SAEI-DEHKORDI S.S., NEMATOLLAHI A., JAFARI, T. Comparative study of heavy metal and trace element accumulation in edible tissues of farmed and wild rainbow trout (Oncorhynchus mykiss) using ICP-OES technique. Microchem. J. 98, 275, 2011.

2. MENDIL D., DEMIRCI Z., TUZEN M., SOYLAK M. Seasonal investigation of trace element contents in commercially valuable fish species from the Black sea, Turkey. Food Chem. Toxicol. 48, 865, 2010.

3. PAPAGIANNIS I., KAGALOU I., LEONARDOS J., PETRIDIS D., KALFAKAKOU V. Copper and zinc in four freshwater fish species from Lake Pamvotis (Greece). Environ. Int. 30, 357, 2004

4. YILMAZ A.B., SANGÜN M.K. YAĞLIOĞLU, D., TURAN C. Metals (major, essential to non-essential) composition of the different tissues of three demersal fish species from Iskenderun Bay, Turkey. Food Chem. 123, 410, 2010.

5. JARIĆ I., VIŠNJIĆ-JEFTIĆ Ž., CVIJANOVIĆ G., GAČIĆ Z., JOVANOVI, L., SKORIĆ S., LENHARDT, M. Determination of differential heavy metal and trace element accumulation in liver, gills, intestine and muscle of starlet (Acipenser ruthenus) from the Danube River in Serbia by ICP-OES. Microchem. J. 98, 77, 2011.

6. AL-YOUSUF M.H., EL-SHAHAWI M.S., AL-GHAIS S.M. Trace metals in liver, skin and muscle of Lethrinus lentjan fish species in relation to body length and sex. Sci. Total 
Environ. 256, 87, 2000.

7. BOCHENEK I., PROTASOWICKI M., BRUCKA-JASTRZĘBSKA E. Concentration of $\mathrm{Cd}, \mathrm{Pb}, \mathrm{Zn}$ and $\mathrm{Cu}$ in roach Rutilus rutilus (L.) from the lower reaches of the Oder River, and their correlation with concentrations of heavy metals in bottom sediments collected in the same area. Arch. Pol. Fish. 16, (1), 21, 2008.

8. CANTLI M., ATLI G. The relationship between heavy metals $(\mathrm{Cd}, \mathrm{Cr}, \mathrm{Cu}, \mathrm{Fe}, \mathrm{Pb}$ and $\mathrm{Zn}$ ) levels and the size of six Mediterranean fish species. Environ. Pollut. 121, 129, 2003.

9. EASTWOOD S., COUTURE P. Seasonal variation in condition and liver metal concentration of yellow perch (Perca flavescens) from a metal-contaminated environment. Aquat. Toxicol. 58, 43, 2002.

10. GRELA E.R., PISARSKI R.K., KOWALCZUK-VASILEV E., RUDNICKA A. Content of nutrients and minerals, and fatty acids profile in some fish flesh depending on fishing period. Żywność. Nauka. Technologia. Jakość. 4, (71), 63, 2010.

11. LIDWIN-KAŹMIERKIWICZM.,POKORSKAK.,PROTASOWICKI M., RAJKOWSKA M. WECHTEROWICZ Z. Content of selected essentials and toxic metals in meat of freshwater fish from West Pomeranian, Poland. Pol. J. Food Nutr. Sci. 59, (3), 219, 2009.

12. AGAH H., LEERMAKERS M., ELSKENS M., REZ FATEMI S.M., BAEYENS W. Accumulation of trace metals in muscle and liver tissue of five fish species from the Persian Gulf. Environ. Monit. Assess. 157, 499, 2009.

13. ESLAMI S., MOGHADDAM A.H., JAFARI N., NABAVI S.F., NABAVI S.M., EBRAHIMZADEH M.A. Trace element level in different tissue of Rutilus frisii kutum collected from Tajan River, Iran. Biol. Trace Elem. Res. 143, 965, 2011.

14. ZUBCOV E., ZUBCOV N., ENE, A., BILETCHI L. Assessment of copper and zinc levels in fish from freshwater ecosystems of Moldova. Environmental Science and Pollution Research, 19, 2238, 2012.

15. YILMAZ A.B. Levels of heavy metals ( $\mathrm{Fe}, \mathrm{Cu}, \mathrm{Ni}, \mathrm{Pb}$ and $\mathrm{Zn}$ ) in tissue of Mugil cephalus and Trachurus mediterraneus from Iskenderun Bay, Turkey. Environ. Res. 92, $277-$ 281, 2003.

16. KUPCEWICZ B., STANEK M., JANICKI B. Chemometric analysis of fatty acids profile of bream (Abramis abramis), ruffe (Gymnocephalus cernua) and perch (Perca fluviatilis) meat from Lake Gopło and Włocławski Dam Reservoir. JCEA. 12, (4), 601, 2011.

17. PEŁECHATY M., OWSIANNY P.M. Horizontal distribution of phytoplankton as related to the spatial heterogeneity of a lake- a case study from two lakes of the Wielkopolski National Park (western Poland). Hydrobiol. 510, 195, 2003.

18. CARLSON R.E. A trophic state index for lakes. Limnol. Oceanogr. 22, (2), 361, 1977.

19. Report of WIOŚ, Water purity of Lake Wędromierz, Zielona Góra 2006.

20. PASZTELANIEC A., KUTYŁA S. The ecological status of lakes in national and landscape parks: Does the location of a lake and its catchments within protected area matter? Pol. J. Environ. Stud. 24, (1), 227, 2015.

21. Report of WIOŚ, Water purity of Lake Strzeszyńskie, Poznań 2012.

22. CHOIŃSKI A. Catalog of Polish lakes, Wyd. UAM, Poznań 2008.

23. BUDZYŃSKA A., SZELĄG-WASILEWSKA E. Species richnes and spatial heterogeity of spring plankton in a lake with varying morphometry. Acta Agrophys. 7, (2), 309, 2006.
24. FISHER M., PRZYBYŁ A., ANDRZEJEWSKI W., MAZURKIEWICZ J., GOLSKI J., PRZYBYLSKA K., RUNOWSKI S. Effects of eutrophication on vendance, Coregonus albula (L.) 1. Limnological characteristics of selected lakes in Wielkopolska. Arch. Pol. Fish. 20, 85, 2012.

25. Report of WIOŚ, Water purity of Lake Góreckie, Poznań 2013.

26. SOBCZYŃSKI T., JONIAK T. Vertical changeability of physical-chemical features of bottom sediments in three lakes, in aspect type of water mixis and intensity of human impact. Pol. J. Environ. Stud. 18, (6), 1093, 2009.

27. KLAVINS M., POTAPOVICS O., RODINOV V. Heavy metals in fish from lakes in Latvia: Concentrations and trends of changes. Bull. Environ. Contam. Toxicol. 82, 96, 2009.

28. RADWAN S., KOWALIK W., KORNIJÓW R. Accumulation of heavy metals in Lake ecosystem. Sci. Total Environ. 96, 121, 1990.

29. YAZDI, R.B., EBRAHIMPOUR M., MANSOURI B., REZAEI M.R., BABAEI H. Contamination of metals in tissues of Ctenopharyngodon idella and Perca fluviatilis, from Anzali Wetland, Iran. Bull. Environ. Contam. Toxicol. 89, 831, 2012.

30. ŁUCZYŃSKA J., TOŃSKA E., ŁUCZYŃSKI M.J. Essential mineral components in the muscles of six freshwater fish from the Mazurian Graet Lakes (northeastern Poland). Arch. Pol. Fish. 17, 171, 2009.

31. RAJKOWSKA M., PROTASOWICKI M. Distribution of metals ( $\mathrm{Fe}, \mathrm{Mn}, \mathrm{Zn}, \mathrm{Cu}$ ) in fish tissues in two lakes of different trophy in Northwestern Poland. Environ. Monit. Assess. 185, 3493, 2013.

32. DURAL M., LUGAL GÖKSU M.Z., AKIF ÖZAK A., DERICI B. Bioaccumulation of some heavy metals in different tissues of Dicentrarchus labrax L, 1758, Sparus aurata L, 1785, and Mugil cephalus L, 1758 from the Çamlik Lagoon of the eastern cost of Mediterranean (Turkey). Environ. Monit. Assess. 118, 65, 2006.

33. BROOKS R.R., RUMSEY D. Heavy metals in some New Zealand commercial sea fishes. N.Z. J. Mar. Fresh. Res. 8, 155, 1974.

34. PETKOVŠEK S.AL S., GRUDNIK Z.M., POKORNY B. Heavy metals and arsenic concentration in ten fish species from the Šalek lakes (Slovenia): assessment of potential human health risk due to fish consumption. Environ. Monit. Assess. 184, 2647, 2012.

35. BRUCKA-JASTRZĘBSKA E., KAWCZUGA D., RAJKOWSKA M., PROTASOWICKI M. Levels of microelements $(\mathrm{Cu}, \mathrm{Zn}, \mathrm{Fe})$ and macroelements $(\mathrm{Mg}, \mathrm{Ca})$ in freshwater fish. J. Elementol. 14, (3), 437, 2009.

36. DRĄG-KOZAK E., ŁUSZCZEK-TROJAN E., POPEK W. Heavy metals iln some tissues and organs of rainbow trout (Oncorhynchus mykiss) fish species in relation to age and season. Environ. Natural Res. 48, 161, 2011.

37. SZEFER P., DOMAGAŁA-WIELOSZEWSKA M., WARZOCHA J., GARBACIK-WESOŁOWSKA A., CIESIELSKI T. Distribution and relationships of mercury, lead, cadmium, copper and zinc in perch (Perca fluviatilis L.) from the Pomeranian Bay and Szczecin Lagoon, southern Baltic. Food Chem. 81, 73, 2003.

38. ALIBABIĆ V., VAHČIĆ N., BAJRAMOVIĆ M. Bioaccumulation of metals in fish of Salmonidae family and the impact on fish meat quality. Environ. Monit. Assess. 131, 439, 2007.

39. BRUCKA-JASTRZĘBSKA E., PROTASOWICKI M. Levels of selected metals in tissues and organs of 5-month-old carp (Cyprinus carpio L.). Acta Sci. Pol., Piscaria 5, (2), 3, 2006. 
